\title{
TNL
}

Sanfilippo-Schulz, Jessica. "Transnational Writing to Aminatta Forna."

Transnational Literature, Vol 13, Oct 2021

Special Edition: Follow the Sun

DOI: https://doi.org/10.33008/TNL.2021.13012

URL: https://transnationalliterature.org

\section{Transnational Writing to Aminatta Forna}

\section{Jessica Sanfilippo-Schulz}

Abstract

I was fascinated by Aminatta Forna's keynote speech at the conference Transnational Literature and Writing: Follow the Sun (2021). This creative-critical and personal letter addressed to Aminatta Forna is a response to her keynote speech about the transnational writer.

\section{Dear Aminatta,}

\section{Germany}

\section{$12^{\text {th }}$ February 2021}

We met a couple of weeks ago, albeit digitally thanks to Zoom's chat feature. I listened to your keynote speech at the end of January at the conference Transnational Literature and Writing: Follow the Sun. Naomi Knox, who hosted the session, called your talk "phenomenal". I have been thinking about the meaning of this word lately and, glaring into darkness at night, I often wonder why it is so fitting for your speech at this specific conference. "Phenomenon" is derived from two Greek words that mean "to appear" and "bring to light". Light up, radiate, shine. All sun-akin words. Your words were indeed illuminating for me and in listening to your speech at dusk while sitting at our small, wooden, kitchen table in northern Germany, I felt that I was turned towards the sun. 


\section{The United States of America}

\section{$14^{\text {th }}$ February 2021}

Hello from the Washington DC area. I'm on the East Coast of the United States.[1]

After so many transnational journeys, you are now teaching in Washington DC. Thinking of your current nation of residence, I envisage a place obsessed with valentine-exchange cards on the $14^{\text {th }}$ February. In terms of transnational settings, you also explained why your third book The Hired Man is set in Croatia and you disclosed that you believe there are many similarities between Croatia and Sierra Leone, where you grew up and where you had, until then, set all your books.

Once upon a time and more precisely from 1918 until 1929, there was a Balkan state called the Kingdom of Serbs, Croats and Slovenes. Today the countries are independent and on this transnational journey with you, I will swiftly cross borders and move from Croatia to Slovenia. Recently, I read that according to Slovenian tradition at springtime, Saint Valentin brings the keys of the roots. Writing to you on the $14^{\text {th }}$ February, a day of fondness and roots, I compose these words to both honour your work and to comment upon your keynote speech about the transnational writer. In unlocking the roots of plants and trees, Saint Valentin acknowledges the arrival of the sun. Winter is over and nature wakes up.

Speaking divinely to us at the conference Follow the Sun, you phenomenated a stimulating discussion about transnational uprootedness. While I write this missive to you on my laptop, outside there is an exceptional snowstorm. We live close to the Dutch border, hence no mountains in sight. It never snows in this area, so the white powder silently piling up on the windowsill of the bedroom is mesmerizing, almost paralysing. I hope that Valentin or this area's patron Saint Liudger, or the deity who is in charge of the weather locally, will be slow in waking up warmth so we can enjoy this fine whiteness a little while longer. It is far too early to unlock the roots. Allende, who you mentioned at the beginning of your speech, once said "I am an eternal foreigner. I don't quite belong anywhere. I was traveling in my childhood as the daughter of diplomats, I have been a political refugee and an immigrant” (Bradshaw). Because she will never completely belong in a place, her roots are in the people she loves and in her books (Conroy). Have you heard that Allende always begins writing her books on the $8^{\text {th }}$ January? Do you have a writing tradition like your transnational peer Allende?

\section{The United Kingdom}

$24^{\text {th }}$ February 2021 
Some years ago, I used to go dog walking near my house in South East London with the neighbour, who was also a psychotherapist. One day he told me about a device psychologists use to determine the way a person sees themselves, how they frame their own identity. He said, "I'm going to ask you ten questions and I want you to answer spontaneously, without hesitation or delay, and your answers must be different each time, no repetition. Shall we begin?". "Yes", I said. "Who are you?"

Transnational FAQs: Who are you? Where do you come from? It was once pointed out to me that when people ask me where I come from I never give a concise answer. Apparently, I frame my identity each time this way: "My mother comes from London, my father is Sicilian, my husband was born in Stuttgart and I was born in Liberia on the West African coast.” During the first semester of the Master's "National and Transnational Studies" programme, our class was given a little form to fill in and we were firstly asked what home means to us. I was a mature student then, I should have been experienced and confident but I seem to recall that I began to sweat. My form remained blank. In my memories, the bell came to my rescue. Yet, the lecturer said we had homework and we were to discuss the answers the following week. That night, while everyone else at home was sleeping, I sought Google's opinion and typed into a rectangular box the phrase "growing up with multiple passports". On a night of autumn 2011, the World Wide Web offered, without hesitation and delay, the answer "Third Culture Kid". As of then my research interests have centred around "Third Culture Literature".

Designer Dieter Rams once said: "A bookcase should be neutral, its life comes from the books it contains" (Lohman). His 606 shelving system has accompanied me from Milano, Italy, to two flats in Stuttgart, Germany, and, after other relocations across Germany, it is now in our living room here. I sometimes stare at its neutral aluminium frame and think that its life and identity come from its journeys from place to place. But the books and dusty objects on it are important too, like a white and red Japanese Maneki cat with one paw raised, tossing good fortune at me. Amidst the "Third Culture Kid" books I have collected, on a shelf is a book of 2004, which contains an excerpt from Allende's Paula. The editors of this collection of personal stories suggest that "Unrooted children have myriad encounters to write about, many cultures to report from, and constant transitions to chronicle" (Eidse and Sichel 5). Contemporary cartoonist Riad Sattouf was born to a French mother and a Syrian father and he too, like you, grew up in multiple countries and has multiple encounters to draw upon. In a series of graphic memoirs, Sattouf describes his childhood spent in Libya, Syria and France. Due to his background, when asked where he comes from he prefers to say that he is a cartoonist, "When I was a teenager I decided to choose for myself another people. I refused France, and Syria. I chose cartoonists" (Cooke). As an unrooted transnational individual, Sattouf paraphrases from Salman Rushdie and claims that "A man does not have roots, he has feet” (Shatz).

Outside, both air and ground temperatures are again above the freezing point and the snow, which is still silently falling, is now melting before it hits the ground in our small shady garden. But north-facing gardens are at times really not that bad, and outside I can still see the abundant 
whiteness of ten days ago and the footprints of my daughter who ran around giggling barefoot in the snow. She had suddenly shouted, "A towel, a towel, I need a towel," and so I took care of the red feet. In this garden, for the time being, the weather Saint cannot unlock the roots. In another article about "Third Culture Kids", I once read that transnational migrants and, especially, "Adult Third Culture Kids" feel at home in airports (Colomer 156). So, on the one hand, we have the idea of roots, and on the other hand there is the notion of floating spaces, of feeling unattached and of flying. Or, as Elif Shafak says (who, by the way, was born in France and raised in Spain, Jordan, Germany and Turkey), roots can be "up in the air", like those of the Tuba tree, which are in the sky, whereas its branches are in the ground (Brenner). Can any of these ideas apply to transnational individuals throughout a lifetime anyway? And, if we don't have roots because we have feet, does a transnational migrant really feel at home walking around airports? I am thinking of Tim Cresswell's chapter in On the Move: Mobility in the Modern Western World about Amsterdam's Schiphol airport, in which he makes it clear through talking to the homeless and migrant taxi drivers that people are not moving "in more or less the same ways" (255). Cresswell's point is that everywhere the elite travel, they are serviced by a mobile workforce and these groups are just as cosmopolitan and transnational as the elite ones.

\section{Canada}

\section{$4^{\text {th }}$ March 2021}

More recently, the writer Kassabova accepted a Scottish literary award and she said: "Last year at the Olympic event Poetry Parnassus, I represented Bulgaria. I accepted the invitation because it was an bonour, but I felt like a fraud - our family emigrated from Bulgaria twenty years ago, and I write in English. In the past, because I was living and publishing in New Zealand, I attended festivals as a New Zealand writer - and, again, I felt like a fraud. Today, I'm honoured to be here as a writer from Scotland, a country I love and feel at home in, and I'm still struggling with that fraudulent feeling."

Antje Rauwerda coined the literary classification "Third Culture Literature" in 2010. Because writer Yann Martel holds a Canadian passport, when he won the Man Booker Prize in 2002 he was on the one hand praised by the Canadian press for his achievement, but on the other hand, as Rauwerda argues, it "launched a controversy about what determines the 'Canadianness' of an author" ("Not Your Typical 'Diaspora”" 17). Martel, a fraudulent Canadian? Journalists, publishers, and academics tend to locate writers and their texts in terms of geography, but in Martel's case this is difficult because, as Rauwerda explains, "there is little accommodation possible for authors whose origin is unclear, or whose 'nationality' includes a lengthy series of countries" ("The Writer and the Overseas Childhood" 4). Due to his parents' careers as diplomats, Martel grew up in Alaska, Canada, Costa Rica, France, Mexico and Spain. You said that your name and 
works are inscribed in two anthologies, one is dedicated to British novels, the other to African novels. Children who grow up frequently migrating in childhood are referred to by sociologists as "Third Culture Kids", and Rauwerda calls novelists who were raised on the move "Third Culture Authors". Allende was raised in Chile, Peru, Bolivia and Lebanon. In an interview, Allende illustrated that she does not want to "be fingerprinted and imprisoned in a confining category not as a female writer or as a political writer or even as a Latin American writer. Just plain novelist will do.” (Mitgang). It is the voice that counts, not the place but the power of the pen. This is your opinion too as a transnational writer.

Right now, I would love to have Miss Smilla's Feeling for Snow and know more about the white powder outside. Peter Hoeg's fictional character, Miss Smilla, from his 1996 novel can name and classify all types of snow and I understand that for many researchers, classification is a crucial part of their work. Shafak's Tuba tree, by the way, would only puzzle biologists and they would find it difficult to classify. It is the mythological Tree of Life that in many cultures stands for eternal life. My crooked magnolia tree outside is starting to blossom, under it are traces of snow. I don't know what to call this type of snow, it has changed so much over the past weeks. I just know that it isn't fluffy and orderly anymore.

\section{Japan}

\section{$21^{\text {st }}$ March 2021}

The transnational may be an immigrant or have immigrant parents or parents from two nations, but crucially chooses to retain links with both, often moving between them. This is Pico Iyer's "Global Soul”.

Outside it is now raining. The rare blue skies and cold crisp temperatures have been replaced by dark clouds. For Rauwerda, the "Third Culture" can be successfully represented by the floating cloud because it drifts at times over Home, at other times over places. Cumulus clouds are "shape-changing and transmogrifying” ("Third Culture Literature” 2015). The "Third Culture Kid" concept has been criticised for its elitist, Anglo-American perspective. Rauwerda, too, initially only examined the fiction of white novelists who write in English and who grew up in privileged expatriate bubbles, but like so many categories, "Third Culture Kid-ness” is not uniform because it can come in many forms and can shift, at times abruptly, at times more casually. Like my snow outside.

Now, I prefer to consider Ruth Van Reken's "Cross-Cultural Kid” model that includes individuals who are living or have "lived in - or meaningfully interacted with - two or more cultural environments for a significant period of time during the first eighteen years of life" (Pollock et al. 43). As Carly McLaughlin points out, this updated approach "takes into account the 
reality of the increasing number of individuals who grow up outside of a traditional monocultural environment" (65). And what about individuals who grow up outside a traditional monolingual environment? Why do we speak about transnational individuals and writers and not about translingual people? As you rightly pointed out in your talk: "The question of language will forever be political. There are ideas and questions I have raised here that I foresee writers, linguists and students of literature grappling with into the future." Like nations, languages are used to symbolise identities but they are very different things. Linguistic identities go beyond national ones at times. You connect transnationalism to the writer Pico Iyer. Rauwerda links him to the "Third Culture Kid” world and for Arianna Dagnino, Iyer is a transcultural writer. For Dagnino, these writers lead neo-nomadic lives and their writings are characterised by their "resistance to appropriations by one single canon or cultural tradition" (144). Born in the UK to Indian parents, Iyer grew up transnationally in the UK and the USA, and he now lives in Japan, a place that he calls his "adopted home" (Gattig). Iyer self-identifies as a "global soul". Sometimes, I think of all the overlapping notions above and they whirl inside my brain giving me a headache. At night, I try to sort each term, each concept, onto neat shelves in my brain but the next day, I find new elements to add to the overcrowded shelves and I do not know how to reshuffle the details I have collected over the years. All these approaches stem from the need to emphasise multiplicity and to reject the notion of belonging to one single place, culture and, sometimes, language. I acknowledge that writers do not want to be put into limiting boxes. What interests me about the "Third Culture Kid" lens though, is that it gives prominence to the specific experience of the migrant child who, for a very long time, has not had a voice. Who is the migrant child? Who does the migrant child become? The "Cross-Cultural Kid" model was established to show children who might feel alienated while navigating the "grey area" of cultural dilemmas that they are not alone (Goana 216). These children might believe they do not belong to the surrounding dominant culture and Van Reken's aim is to find ways to bring together these individuals "of all nationalities, races, ethnicities, gender, class and economic levels who have experienced growing up among many cultural worlds for any reason” (Van Reken 58). In a way, isn't this idea of a shared experience that links people who were raised outside of a dominant culture like the snow? Snow is a unifier, I think, recalling waking up the day I began writing this letter to you. Outside, the plants, trees, cars, buildings, decorations, litter were alike. They were all covered by the same snow. My barefoot in the snow daughter is my very own “Cross-Cultural Kid”. Seventeen years ago we began imposing three languages and cultures on her and at the beginning I wondered whether it would overwhelm her. But she has giggled through this transmogrifying experience too, embracing and collecting new languages and cultures along her journey, sometimes orderly, sometimes chaotically. 


\section{Sierra Leone and Scotland}

\section{$4^{\text {th }}$ April 2021}

My transnational background has provided me with a particular vantage point in examining two different continents. I saw the differences, which were specific to that place but mainly I saw the similarities.

After a three-day heat wave at the end of March, it is snowing again and for the first time ever, I am experiencing a white Easter. In order to promote the Historical Thesaurus of Scots, in 2015, a lecturer in English and Scottish Language at the University of Glasgow claimed that Scotland has more than 400 words and expressions for snow (Rennie). This sounds fascinating but when examining this Thesaurus, I could only find eight words for "snow". During the question and answer session, you say that it:

is in the ladies bathroom, right when women are talking in front of the mirror they actually talk about the experience of being a woman, they don't talk about the experience of being English or Jamaican or Bolivian. They talk about the experience of being a woman and again you get those micro conversations where people start crossing over and talking about experience.

Perhaps, it is then in this place that I should end my letter to you. In a place of shared experiences and in this transnational space of ours, that is intermediate between localities and the globe. Almost two months have passed since I began writing to you and once again, I am in my bedroom in northern Germany staring at snowflakes. Across time and place, I have examined with you the properties of snow and only now I realize that this natural phenomenon, between fluid water and solid ice, is always in an intermediary state too. Perhaps, then I can put concepts on my shelf more tidily tonight. I will put transculturalism and cross-culturalism side by side because they share similarities although the focus of "Cross-Cultural Kids" is on a community of shared cross-cultural experiences after having been raised among many cultures. On the other hand, transnationalism focuses, as you said in the discussion after your presentation, on nations and location. And, I would conclude that for transnational writers, the sense of belonging is ultimately in their books and not in a single place or culture. Shafak writes: "There is more overlap, there is always greater possibility of finding common ground between people of multiple belongings [than] between people of mutually exclusive identities" (2020). The pen and voice of the writer who grew up with multiplicities is forceful. Dear Aminatta, I know that in times of darkness, conflict, racism 
and of rising xenophobia, individuals and writers like you will always rise and shine, bringing us transcultural, transnational, global, cross-cultural understanding - and phenomenal times.

My deepest admiration and sunny regards,

Jessica

[1] The quotations at the beginning of each section are from Aminatta Forna's keynote speech at the conference Transnational Literature and Writing: Follow the Sun, $28^{\text {th }}$ January 2021, and the discussion after this talk.

\section{WORKS CITED}

Bradshaw, Megan. "In Conversation with Isabel Allende”. Asymptote Blog, 14 December 2015, www.asymptotejournal.com/blog/2015/12/14/in-conversation-with-isabel-allende/.

Brenner, Angie. "Elif Shafak: A Writer on the Edge of Her Culture". Wild River Review, vol. 1, no. 1, 2006, section Spotlight,www.elifsafak.us/en/roportajlar.asp?islem=roportaj\&id=6.

Colomer, Laia. "Feeling like at Home in Airports: Experiences, Memories and Affects of Placeness among Third Culture Kids”. Applied Mobilities, vol. 5, no. 2, 2020, pp. 155-170.

Conroy, Catherine. "Isabel Allende: 'Where Are My Roots? They Are in My Books'”. The Irish Times, 18 January 2020, www.irishtimes.com/culture/books/isabel-allende-where-are-my-roots-they-are-in-my-books-1.413 1819.

Cooke, Rachel. "Riad Sattouf: Not French, Not Syrian... I'm a Cartoonist”. The Observer, 27 March, 2016, www.theguardian.com/books/2016/mar/27/riad-sattouf-arab-of-the-future-interview.

Cresswell, Tim. On the Move: Mobility in the Modern Western World. Routledge, 2006.

Dagnino, Arianna. Transcultural Writers and Novels in the Age of Global Mobility. Purdue University Press, 2015.

Eidse, Faith, and Nina Sichel, editors. Unrooted Childhoods: Memoirs of Growing Up Global. Nicholas Brealey and Intercultural Books, 2004. 
Gattig, Nicolas. "Can You Ever Really Understand Japan? Pico Iyer Offers Help”. The Japan Times, 19 October 2019,

www.japantimes.co.jp/culture/2019/10/19/books/beginners-guide-japan-observations-provocatio ns-pico-iyer-224-pages/.

Goana, Anastasia. "Exploring Enoughness in Third Culture Kids". Shades of Noir Journals, March 2021, pp. 216-221.

Høeg, Peter. Miss Smilla's Feeling for Snow. Harvill, 1996.

Lohman, Birgit. "Dieter Rams in Unreleased Video Interview from 2000, Treasures on Tape". Designboom, 29 January 2020, www.designboom.com/design/dieter-rams-video-interview-treasures-on-tape-01-29-2020/.

McLaughlin, Carly. "Childhood, Migration, and Identity in Chris Cleave’s The Other Hand". Transcultural Identities in Contemporary Literature, edited by Irene Gilsenan Nordin et al., Rodopi, 2013, pp. 47-67.

Mitgang, Herbert. "As Isabel Allende Sees Herself". The New York Times, 4 February 1988, www.nytimes.com/1988/02/04/books/as-isabel-allende-sees-herself.html.

Pollock, David C., et al. Third Culture Kids: The Experience of Growing Up Among Worlds. 3rd ed., Nicholas Brealey Publishing, 2017.

Rauwerda, Antje M. “Not Your Typical 'Diaspora' or 'Third World Cosmopolitan': Unexpectedly International Writing”. Wasafiri, vol. 25, no. 3, September 2010, pp. 16-23.

---. The Writer and the Overseas Childhood: The Third Culture Literature of Kingsolver, McEwan and Others. McFarland, 2012.

---. "Third Culture Literature: We Are Cumulus: Third Culture as a Cloud”. Third Culture

Literature, 12 August 2015,

www.thirdcultureliterature.blogspot.com/2015/08/we-are-cumulus-third-culture-as-cloud.html.

Rennie, Susan, editor. "Snow”. Historical Thesaurus of Scots, University of Glasgow, School of Critical Studies, September 2015, www.scotsthesaurus.org/.

Shafak, Elif. "Elif Shafak on What It Means to Belong in Many Places at Once". Literary Hub, 9 October 2020, www.lithub.com/elif-shafak-on-what-it-means-to-belong-in-many-places-at-once/.

Shatz, Adam. "Drawing Blood: A French Graphic Novelist's Shocking Memoir of the Middle East”. The New Yorker - Magazine, 12 October 2015, www.newyorker.com/magazine/2015/10/19/drawing-blood. 
Van Reken, Ruth. "Peer Review: Ruth E. Van Reken”. Shades of Noir Journals, March 2021, pp. 46-59.

\section{Jessica Sanfilippo-Schulz}

Jessica Sanfilippo-Schulz is a doctoral researcher at the University of Leeds. Currently, she is a visiting scholar at the Graduate School 'Practices of Literature' of the University of Münster. Her thesis explores life writing about frequent international mobility in girlhood. Jessica is also passionate about creative writing. 